\title{
口蓋垂口蓋咽頭形成術適応予測值の検討
}

\author{
且井 信郎・川野 和弘・石橋まどか \\ 岡村 一成・伊藤 浩一

\section{Investigation of Predictive Values as the Criteria for Indication of Uvulopalatopharyngoplasty}

\author{
Nobuo Usui, Kazuhiro Kawano, Madoka Ishibasi, \\ Kazunari Okamura and Koichi Ito \\ (Toho University)
}

\begin{abstract}
Purpose : To determine whether preoperative physical examination, physiological examination, and MRI examination of the upper respiratory tract can yield predictive values for the indication of uvulopalatopharyngoplasty (UPPP).

Subjects and Methods : Thirty-seven patients who completed preoperative and 3-6 monthpostoperative follow-up examinations, examination of nocturnal sleep and respiratory resistance via the nose and the mouth, and upper respiratory MRI examination were investigated.

Results : The AHI improvement rate was calculated using preoperative and postoperative AHI, and the correlation between the AHI improvement rate and the results of preoperative physical examination, physiological examination, and upper respiratory MRI examination was investigated. There was a significant positive correlation between the AHI improvement rate and the preoperative AHI $(r=0.471, p=0.0033)$, body weight $(r=0.496, p=0.0018)$, and BMI $(r=0.438, p=0.0067)$. The sensitivity and specificity were $77 \%$ and $83 \%$, respectively, if calculated with $\mathrm{AHI}=30 ; 84 \%$ and $83 \%$, respectively, if calculated with weight $=70 \mathrm{~kg}$; and $61 \%$ and $83 \%$, respectively, if calculated with $\mathrm{BMI}=26 \mathrm{~kg} / \mathrm{m}^{2}$.

Conclusion : A higher AHI, weight, and BMI resulted in increased AHI improvement rates, and the predictive values for UPPP were considered to be $A H I \geqq 30$, weight $\geqq 70 \mathrm{~kg}$, and $\mathrm{BMI} \geqq 26$ $\mathrm{kg} / \mathrm{m}^{2}$.
\end{abstract}

Key words : predictive values of UPPP, uvulopalatopharyngoplasty, AHI improvement rate

\section{はじめに}

口蓋垂口蓋咽頭形成術 (uvulopalatopharyngoplasty, UPPP) は閉塞性睡眠時無呼吸症候群 (obstructive sleep apnea syndrome, OSAS) の外科的治療法として, 広く 施行されているが，しばしば治療効果がそしいといわれ ている1).われわれは OSAS に対する外科的治療法の第 1 選択としてUPPPを施行してきたが，術前・術後の AHI (無呼吸-低換気指数, apnea hypopnea index) 改
善率でみた場合，25\%以上の改善率は症例数の $75 \%$ でま ずまずの成績と思われたが，50\%以上の改善率は症例数 の56.3\%で決して満足できる成績ではなかった. OSAS に対する術前の検查值から UPPP によく反応する患者 を識別する基準を見い出すことができればUPPP の成 績を上げることが可能である. そこで今回，1 人の術者 による 9 年間の UPPP 症例を術前・術後に拉ける身体 検查, 生理学的検查そして上気道 MRI 検查をもとに検 
討し，UPPPの適応子測値を導くことができるかどう か検討した.

\section{対 象}

1990年から1998年の間に同一術者が UPPPを施行し， 術前之術後 $3 \sim 6$ 力月後に身体検査, 終夜睡眠検查, 鼻 之口呼吸時の呼吸抵抗検査, そして上気道 $M R I$ 検查の すべてを施行できた37症例を対象とした。

\section{方法}

1. 身体検査: 身長, 体重, BMI (肥満指数, body mass index) を測定した(表 1 ).

2. 終夜睡眠検查 : ポータブル睡眠呼吸障害モニター ・マイクロスリープ (Synectics Medical Products 製) を 用いて, 術前・術後の無呼吸, 低換気, 動脈血酸素飽和 度，体位，いびき，心拍，周期性呼吸などを入院の上個 室で測定した。

3. 鼻と口呼吸時の呼吸抵抗検查: 総合鼻腔通気度測 定装置・ライノグラフ (TUC-5600M 型チェスト社製)を 用いて，両側鼻呼吸抵抗と口呼吸抵抗を坐位にて測定し た.

4.上気道 MRI 計測法 : 正中矢状断に执いて, 第 2 頸椎上端前後径長 $(A)$, 切歯根から硬口蓋までの長さを 硬口蓋長 ( a ), 硬口蓋後端から口蓋垂先端までの長さを 軟口蓋長 (b), 硬口蓋後端之舌骨前上縁を結ぶ線上の舌 上下端にわたる長さを舌上下長 (c), 舌上下長の中点で 直角に交差する線上の舌前後端にわたる長さを舌前後長 (d)，下顎骨前下端と第 2 頸椎下端を結ぶ下顎長 $(e)$ と した(図 1 )。水平断(図 2 )では, 左右下顎枝と口蓋縫合 および咽頭腔に口蓋垂が見光るレベルで，咽頭腔左右径 (f) と咽頭腔前後径 $(\mathrm{g})$ をノギスで計測した。これらの 計測值 $(\mathrm{cm})$ は実際の值とは異なり，そのままでは比較

表 1 術前の身体検查值 (平均值士S.D)

\begin{tabular}{c|c}
\hline \hline 被 検 者 数 & 37 \\
\hline 性 $($ 男性 : 女性 $)$ & $35: 2$ \\
\hline 年齢 $($ 歳 $)$ & $43.92 \pm 12.64$ \\
\hline 身長 $(\mathrm{cm})$ & $166.18 \pm 6.55$ \\
\hline 体重 $(\mathrm{kg})$ & $74.70 \pm 12.20$ \\
\hline BMI $\left(\mathrm{kg} / \mathrm{m}^{2}\right)$ & $26.79 \pm 3.49$
\end{tabular}

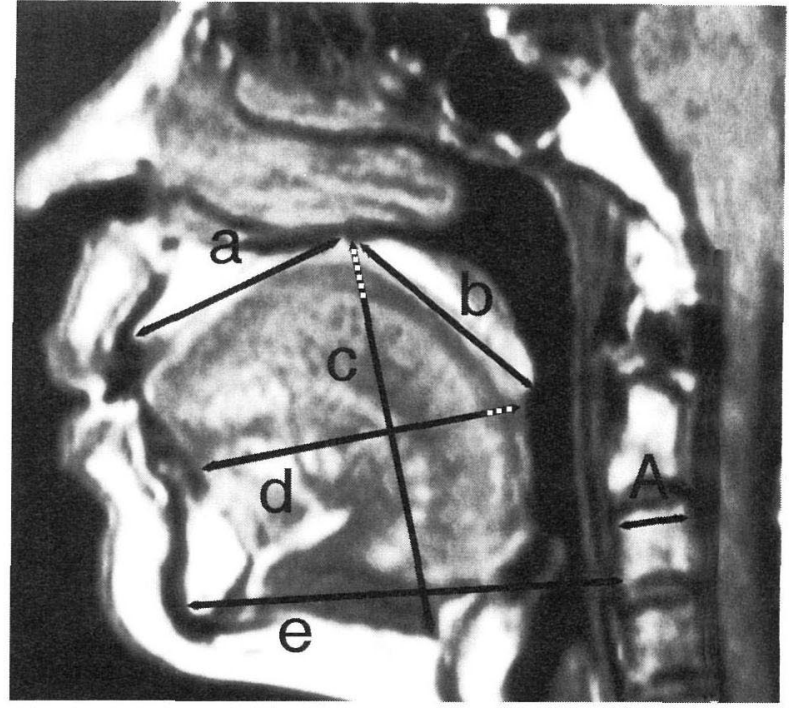

図 1 MRI 正中矢状断に括ける計測法

$A$ : 第 2 頸惟上端前後径長, $\mathrm{a}$ : 硬口蓋長, $\mathrm{b}$ : 軟口蓋長, $c$ ：舌上下長, $d$ ：舌前後長, e : 下顎長

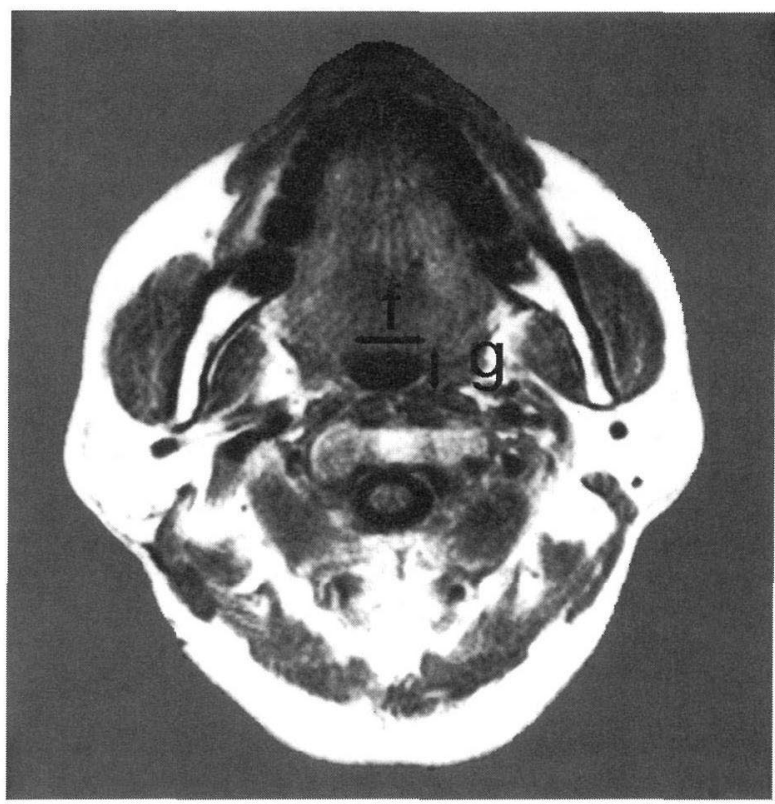

図 2 MRI 水平断に扮ける計測法 $\mathrm{f}$ : 咽頭腔左右径, $\mathrm{g}$ : 咽頭腔前後径

できないため第 2 頸椎上端前後径長 $(A)$ を補正値として 各計測值を除し，得られた值を測定值とした。

5. AHI 改善率の求め方 : 終夜睡眠検査データから 睡眠呼吸障害の診断基準として広く採用されている 
AHI を用いて, 術前・術後の AHI から AHI 改善率を 求めた。

$$
\mathrm{AHI} \text { 改善率 }=\frac{\text { 術後 } \mathrm{AHI}-\text { 術前 } \mathrm{AHI}}{\text { 術前 } \mathrm{AHI}} \times 100
$$

6. 検討項目 : 術前の身体検査値から年龄, 身長, 体 重, BMI の 4 項目, 術前の生理学的検査值から AHI, 鼻呼吸抵抗, 口呼吸抵抗の 3 項目, そして術前の上気道 MRI 測定値から 7 項目の合計14項目について AHI 改善 率との間の相関関係を調べた。

\section{結果 \\ 1. 身体検査値加}

AHI 改善率と体重 $(r=0.496, p=0.0018)$ (図 3$)$, BMI ( $\mathrm{r}=0.438, \mathrm{p}=0.0067)$ (図 4 ) との間に有意な相関 関係が認められた. 感受性 (sensitivity) と特異性 (specificity) は，それぞれ，体重=70 kg の場合，84\%と83\%， $\mathrm{BMI}=26 \mathrm{~kg} / \mathrm{m}^{2}$ の場合， $61 \%$ と $83 \%$ であった。すなわ ち, 体重の重い方が, 同様に BMI も高い方が AHI 改 善率はよかった。

\section{2 . 生理学的検査値加}

AHI 改善率と術前の AHI $(r=0.471, \mathrm{p}=0.0033)$ と の間に有意な相関関係が認められた(図 5 ). sensitivity と specificity は $\mathrm{AHI}=30$ の場合， $77 \%$ と3\%であった。 すなわち, AHI が高い方が AHI 改善率はよかった.な お，鼻呼吸抵抗と口呼吸抵抗には AHI 改善率との間に 有意な相関関係を認めることはできなかった。

3 . 上気道 MRI 測定值から

7 項目すべてに执いて，AHI 改善率との間に有意な

\section{(kg)}

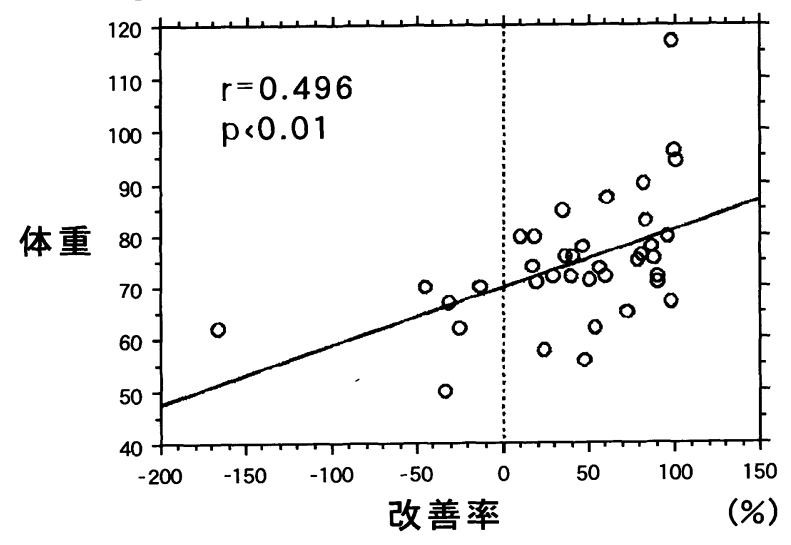

図 3 AHI 改善率と術前の体重との関係

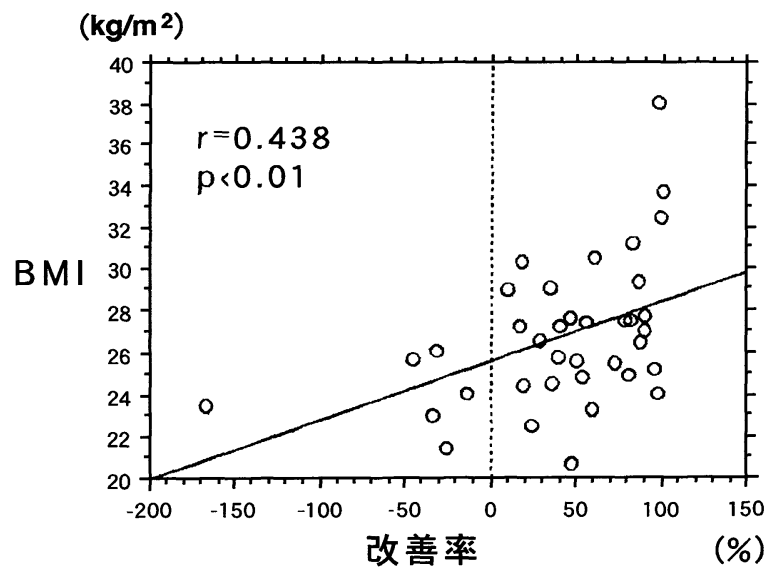

図 4 AHI 改善率と術前の BMI との関係

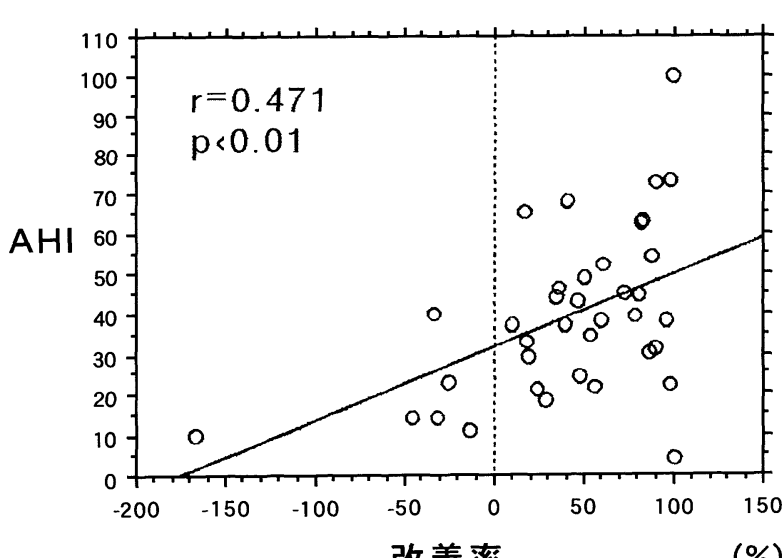

図 5 AHI 改善率と術前の AHI との関係

相関関係は認められなかった.

\section{考察}

OSAS は病歴, 身体検査, 画像検査としてポリソム ノグラフィーなどによって診断されている. しかし，手 術適応の可否を識別するための予測值は見い出だされて いない2．われわれはMRIによって上気道狭窄や上気 道虚脱の過程を理解でさたが，手術適応に関連する臨床 的手段を得ることはできなかっだ). ポリソムノグラ フィックな終夜睡眠検査は睡眠に関連する呼吸障害の診 断に関する基準となっている.そこで，われわれは睡眠 呼吸障害の診断基準として広く採用されている AHIを 用いて, 術前・術後の AHI より AHI 改善率を求め, AHI 改善率と術前の身体検査, 生理学的検査そして上 
気道 MRI 検査の各測定値との間の相関関係を調べ検討 した. その結果, 術前の AHI, 体重として BMI が UPPP 予測値として有意に高く評価された.

Schwartz ら4) は UPPP への反応は肥満の程度や OSAS の程度によって影響されなかったが，OSASを有する 典型的な患者はしばしば太った人であると述べている。 従来，OSAS と関連する身体的所見はBMIを除いては 明らかではないといわれてきた2). 事実, Woodson ら5) は AHI はBMI に有意に相関したと報告し, Riley ら6) は術前の肥満は UPPP の成績にマイナスの予測要因と なると述べている．He ら7) は平均 BMI $36.5 \pm 7.4 \mathrm{~kg} /$ $\mathrm{m}^{2}$ の UPPP 治療患者 60 人について, 8 年間の長期経過 観察を行った結果, $\mathrm{AI}>20$ と診断された患者では死亡 率が増加したと報告し，それ以来，UPPPは不評を買っ てきた. 最近, Lysdahl ら ${ }^{8)}$ は平均 BMI $27.1 \pm 3.2 \mathrm{~kg} /$ $\mathrm{m}^{2}$ の UPPP を受けた 256 人について $5 \sim 9$ 年間の長期 経過観察を行った結果，UPPPは $\mathrm{AI}>20$ の患者に扣い て，長期的死亡率によい影響を及ぼしたと報告し，その 相違は北米の OSAS 患者はスカンジナビアの患者でみ られる平均的肥満度をはるかに上回って拉り， $\mathrm{AI}$ より も肥満が死亡率に影響すると述べている。われわれの 37 症例の平均 BMI は $26.79 \pm 3.49 \mathrm{~kg} / \mathrm{m}^{2}$ であり, 北米の OSAS 患者と比較した場合，スカンジナビアの患者と 同様，非肥満者の範疇に属するものと思われた. OSAS に扐ける体重と BMI はともに肥満に関連するパラメー ターであるが，正確にUPPP の適応を予測するために は単一のデータだけでない方がよいと考えられた。

生理学的検査値について, Miljeteig ら ${ }^{9)}$ は UPPP 前後 でAHI に有意差は認められなかったと報告し, Schwartz ら4)はポリソムノグラフ・パラメーターを基に UPPP 症例を検討したが，術前に改善例あるいは非改善例を予 測することはできなかったとし，UPPPは睡眠時の上 気道障害を軽減する目的で行われる OSAS の決定的治 療法となりらると考兄られるのに，無選択の症例に拀い てはなぜ約半数にのみ有効であるのかはっきりしないと 述べている.これに対して, Philip-Joet ら ${ }^{10)}$, Rey $5^{11)}$ は術前の $\mathrm{AI}<40$ は UPPP 成功の確実な予測値となり 得るとし, われわれの結果とは反対に, 重症な OSAS には効果が少ないと述べている. Strohl ら ${ }^{12)}$ は AI $>5$, あるいは AHI > 20 の OSAS 患者が保存的治療あるいは UPPP で治療された場合, 死亡率を増加させたと報告

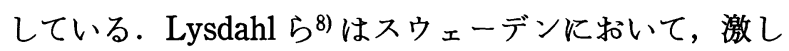

いいびきを有する非肥満者に扣けるUPPP 後の長期生 存について調べた結果, 長期的死亡率はいびきあるいは 睡眠時無呼吸を有する患者のどちらに打いても増加して おらず，それゆ穴に，非肥満者のOSASの口蓋手術は 長期生存にプラスの効果を及法したと述べている.われ われの症例は Lysdahl ら ${ }^{8)}$ の症例よりもさらに BMI が 低かったことから, 非肥満者に位置付けられるものと思 われた。呼吸抵抗検査では, 口呼吸抵抗の増加が舌根部 レベルの狭窄を示唆することから ${ }^{13)}, \mathrm{UPPP}$ 適応予測值 を導くことができるのではないかと期待されたが，AHI 改善率との間に有意な相関関係を認めることはできな かった.

上気道 MRI 測定值については，われわれの MRI 測 定值から UPPP 予測值を導きだすことはできなかった。 Shepard ら ${ }^{14)}$ はCTによって上気道の特徽的所見を確 認し，それによって手術成果を予測できるかどうか検討 したが，改善群と非改善群との相違をセファロメトリッ クな測定で見い出すことはできなかったとし， Langin ら ${ }^{15)}$ は UPPP 後の CT 画像の変化は軟口蓋の長さの減 少と幅の増加のみであったと述べ, Woodson ら5) は頭 部と頸部の検査, 内視鏡, セファロメトリーは OSAS 手術の成功予測に乏しかったと報告している. Friedman $5^{2)}$ はX 線検查や MRI は上気道狭窄や上気道虚脱 の過程を詳細に理解可能にしたが，呼吸障害を明確に診 断するための臨床的・効率的手段とはなり得なかったと 述べている.そして，UPPPに対する術前の予測とし ては口蓋扁桃の大きさが関連するのではないかと考光, Schwartz ら")そして Hudgel ら ${ }^{16)}$ も同様の見解であっ た. 口蓋扁桃の関与の有無はわれわれの今回の検討から ではわからなかったが，口蓋扁桃は OSAS の治療に抽 いて，一般に最も手術的対象とされる部位であり，その 関与の度合については今後検討する必要がある.

UPPP 適応基準を確立することは nCPAP (経鼻的持 続陽圧呼吸, continuous positive airway pressure via the nasal route)による厄介な治療を何年間も続けるこ となく，此較的容易な手術的方法を選択できる機会を与 えるものである，それゆ光に，UPPPによく反応する 患者選択に役立つ基準を確立することが大切である. UPPP の患者選択に役立つ術前の基準を確立するため 飞術前・術後の $\mathrm{AHI}$ より $\mathrm{AHI}$ 改善率を求め, 術前の 身体検查値, 生理学的検查値, そして上気道 MRI 測定 値より OSAS 手術適応予測值を検討した。 その結果, 
AHI，体重，そしてBMI が UPPP 予測值として識別に 役立つものと思われた。

$$
\text { まとめ }
$$

AHI 改善率でみた場合，AHI，体重，BMI は高い方 が有意に改善率はよかった。したがって，UPPPは $\mathrm{AHI} \geqq 30, \quad$ 体重 $\geqq 70 \mathrm{~kg}, \mathrm{BMI} \geqq 26 \mathrm{~kg} / \mathrm{m}^{2}$ が適応予測値 と考えられた.

\section{参考文献}

1) Cartwright $R:$ Who should treat sleep apnea and how? Chest $111:$ 266 267, 1997.

2) Friedman M, Tanyeri H, La Rosa M, et al : Clinical predictors of obstructive sleep apnea. Laryngoscope 109 : 1901 1907, 1999.

3 ）白井信郎, 川野和弘, 伊藤浩一 : 閉塞性睡眠時無呼吸症候 群の MRI. 口咽科 $11: 433 \sim 439,1999$.

4) Schwartz AR, Schubert N, Rothman W, et al : Effect of uvulopalatopharyngoplasty on upper airway collapsibility in obstructive sleep apnea. Am Rev Respir Dis 145 : $527 \sim 532,1992$.

5 ) Woodson BT and Naganuma H : Comparison of methods of airway evaluation in obstructive sleep apnea syndrome. Otolaryngol Head Neck Surg 120 : 460 463, 1999.

6 ) Riley RW, Powell NB, Li KK, et al : Surgery and obstructive sleep apnea ; long-term clinical outcomes. Otolaryngol Head Neck Surg $122: 415 \sim 421,2000$.

7 ) $\mathrm{He} \mathrm{J}$, Kryger MH, Zorick FJ, et al : Mortality and apnea index in obstructive sleep apnea ; experience in 385 male patients. Chest $94: 9 \sim 14,1988$.

8 ) Lysdahl M and Haraldsson PO : Long-term survival after uvulopalatopharyngoplasty in nonobese heavy snorers; a 5-to 9-year follow-up of 400 consecutive patients. Arch
Otolaryngol Head Neck Surg 126 : 1136 1140, 2000.

9 ) Miljeteig H, Mateika S, Haight JS, et al : Subjective and objective assessment of uvulopalatopharyngoplasty for treatment of snoring and obstructive sleep apnea. Am J Respir Crit Care Med 150 : 1286 1290, 1994.

10) Philip-Joet F, Rey M, Triglia JM, et al : Uvulopalatopharyngoplasty in snorers with sleep apnea; predictive value of presurgical polysomnography. Respiration 58 : 100 105, 1991.

11) Rey M, Philip-Joet F, Reynaud M, et al : Relation between polysomnographic parameters and apnea index in obstructive sleep apnea syndrome. Respiration $61: 14 \sim 18$, 1994.

12) Strohl KP and Redline S : Recognition of obstructive sleep apnea. Am J Respir Crit Care Med 154 : 279 289, 1996.

13）臼井信郎，川野和弘：気流抵抗検査による閉塞性睡眠時無 呼吸症候群の手術適応基準. 口咽科 $10: 191 \sim 199,1998$.

14) Shepard JW Jr and Thawley SE : Evaluation of the upper airway by computerized tomography in patients undergoing uvulopalatopharyngoplasty for obstructive sleep apnea. Am Rev Respir Dis $140: 711 \sim 716,1989$.

15) Langin T, Pepin J, Pendlebury S, et al : Upper airway changes in snorers and mild sleep apnea sufferers after uvulopalatopharyngoplasty (UPPP). Chest $133: 1595 \sim$ 1603, 1998.

16) Hudgel DW, Harasick T, Katz RL, et al : Uvulopalatopharyngoplasty in obstructive apnea; value of preoperative localization of site of upper airway narrowing during sleep. Am Rev Respir Dis 143 : 942 946, 1991.

$\left.\begin{array}{l}\text { 原稿受付 : 平成12年12月11日 } \\ \text { 原稿採択 : 平成13年 } 1 \text { 月 } 24 \text { 日 } \\ \text { 別刷請求先 : 臼井信郎 } \\ \text { †153-8515 東京都目黒区大橋2-17-6 } \\ \text { 東邦大学医学部耳鼻咽喉科学第 2 講座 }\end{array}\right)$

